\title{
A VERDADE E $O$ ENGODO DO DESEJO NA LEITURA DO SEMINÁRIO A ANGÚSTIA DE JACQUES LACAN
}

\author{
Daniela Teixeira Dutra Viola, Ângela Maria Resende Vorcaro
}

Daniela Teixeira Dutra
Viola
Psicanalista,
psicóloga graduada
pela UFMG,
especialista em
Teoria Psicanalítica
e mestre em
Psicologia na
área de Estudos
Psicanalíticos pela
UFMG.
Ângela Maria Resende
Vorcaro
Professora adjunta
do departamento
de psicologia da
UFMG. Graduada
em Psicologia
pela PUC-MG, é
mestre e doutora
em Psicologia pela
PUC-SP. É também
membro do corpo
editorial da revista
Estilos da Clínica
(USP).

RESUMO: Discute-se uma vertente do Seminário 10, A angústia, de Lacan (1962-1963) no qual o autor elabora uma oposição entre a dimensão enganosa do desejo — presente principalmente no nível em que o objeto a assume a forma visual — e a verdade que é sinalizada pela angústia, na medida em que tal afeto é definido nessa obra como o que não engana. Essa investigação é circunscrita no Seminário 10 e, assim, visa-se localizar a extração do objeto a nessa construção lacaniana sem pretender abarcar todas as suas consequências, que são definidas apenas nos seminários subsequentes.

Palavras-chave: psicanálise, angústia, verdade, desejo, objeto a.

ABSTRACT: The truth and the bait of desire in the readings of the anguish Seminars of Jacques Lacan. The present article discusses a slope of the Seminar 10, The anguish, of Lacan (1962-1963) in which this author prepares an opposition between the deceiving dimension of the desire - present mainly in the level in which the object a assumes the visual form - and the truth that is signaled by the anguish, as such affection is defined in this work as what it does not deceive. This investigation is limited to the Seminar 10 , and that is why it aims to locate the extraction of the object a from this Lacanian construction without intending to discuss all its consequences, which will be defined in later Seminars.

Keywords: psychoanalysis, anguish, truth, desire, object a. 


\section{A REORDENAÇÃO DA TEORIA LACANIANA DO DESEJO A PARTIR DA FORMULAÇÃO DO OBJETO $A$}

Pretende-se examinar um dos meandros percorridos por Lacan no Seminário 10, A angústia (1962-1963). Propomo-nos a discutir um recorte circunscrito na reflexão desse autor acerca da vertente enganosa do desejo e da verdade sinalizada pela angústia, afeto definido nessa obra como o que não engana. Consideramos que tal reflexão é fundamental para compreendermos a função da abordagem lacaniana da angústia nesse contexto teórico. É justamente essa abordagem que possibilita a formulação do objeto a — noção crucial no ensino de Lacan. Para demonstrar como essa formulação está atrelada à reflexão que focalizamos neste estudo, recorremos a três autores contemporâneos que empreendem valiosas leituras do Seminário 10: Bernard Baas (2001), Marcus André Vieira (2001) e Jacques-Alain Miller (2005).

Como ressalta Miller (2005), a extração do objeto a só é possível nesse contexto teórico porque a angústia é uma via não-significante, é um afeto que sinaliza o que está fora da linguagem. Como sinal, a angústia demarca a certeza antecipada para o sujeito, certeza súbita de sua condição de objeto. É esta a verdade sinalizada pela angústia: a verdade do sujeito, objetificada em um pedaço do corpo, em um resto. Portanto, é necessário enfatizar que a verdade debatida no âmbito do Seminário 10 ainda não apresenta o estatuto que Lacan lhe atribui, sobretudo em relação ao saber, na teoria dos quatro discursos - o que só vem a ocorrer a partir dos Seminários 16 (1968-1969) e 17 (1969-1970). Limitamonos aqui a abordar a verdade como oposição ao engodo, como Lacan explicita na afirmação de que o desejo é ilusão e que isso "só pode ser uma referência ao registro da verdade" (LACAN, 1963, p.245). As demais vicissitudes do problema da verdade no pensamento lacaniano não serão aqui contempladas. Trata-se, antes, da verdade como o que não engana da angústia.

No decorrer do ensino de Lacan, torna-se cada vez mais evidente que a verdade não pode ser enunciada em sua totalidade, como já supõe Freud desde seus primeiros postulados acerca da histeria. Dessa maneira, a partir do legado das obras de Freud e de Lacan, compreende-se a verdade como algo da ordem da ficção, posto que o sujeito só tem acesso a essa verdade pela via do significante. No entanto, essa verdade, que só pode aparecer nos interstícios do dizer, ocasionalmente irrompe, em um átimo, deflagrada pela angústia. Eis aí a certeza do sujeito. É nesse sentido que Lacan opõe a verdade ao engano nesse Seminário, e essa oposição é crucial para a introdução do objeto a na teoria lacaniana. A extração do objeto a garante um movimento conceitual sem precedentes no ensino lacaniano, sobretudo em função do aprimoramento que ela viabiliza na teoria do desejo e da abertura que é vislumbrada para uma articulação lógica entre os três registros (real, simbólico e imaginário). Vejamos, então, em uma 
breve digressão, como o trajeto que Lacan constrói norteado pelo problema da angústia culmina em um ponto que representa uma dobradiça conceitual em sua obra.

Lacan percorre o caminho aberto por Freud, que dedica parte considerável de sua trajetória à compreensão da angústia. A pesquisa freudiana conclui que a angústia é um afeto arcaico, anterior ao recalque e desencadeador dos processos defensivos. Como um afeto primitivo, a angústia tem a função de sinalizar a iminência de um perigo pulsional. O percurso freudiano sobre a angústia, que culmina na obra Inibição, sintomas e ansiedade (1926), é norteado pela busca de um objeto para esse afeto. No entanto, Freud não chega a uma concepção definitiva do que seria tal objeto. Ao procurar a causa da angústia em vivências muito precoces do bebê, como no ato do nascimento, esse autor chega a um paradoxo, visto que nesses momentos primitivos não há propriamente um objeto. Freud tenta solucionar esse impasse em seu último trabalho sobre a angústia, a Nova conferência introdutória “Ansiedade e vida instintual” (1933). Nessa abordagem, atribui à experiência originária de angústia um excesso libidinal com o qual a criança não consegue lidar. Trata-se de uma vivência traumática, cuja intensidade é atualizada no decorrer da vida do sujeito em experiências que, de alguma maneira, reeditam esse excesso libidinal. A angústia é o afeto que acompanha a atualização desse excesso.

Essa breve recapitulação da trajetória de Freud no rastro da angústia é fundamental para a compreensão do ponto de partida de Lacan. Se Freud se vê às voltas com o objeto indiscernível da angústia, Lacan utiliza a própria angústia para formular um objeto até então impensável, mas que, não obstante, é essencial para todo o prosseguimento da sua teoria do desejo. A letra a designa o resto da operação de constituição do sujeito na linguagem. É um resto irredutível ao significante, borda entre o real e o simbólico. Como borda, o a é a causa do desejo, o que está por trás da metonímia significante que constitui o desejo.

Lacan esclarece que escolheu o tema da angústia para seu décimo seminário “porque esse caminho revivifica toda a dialética do desejo, e porque é o único que nos permite introduzir uma nova clareza quanto à função do objeto em relação ao desejo" (LACAN, 1963, p.252-253). A conexão do desejo com a angústia já aparece no Seminário 8 (LACAN, 1961), e a noção de objeto a é consequência de certa tensão ao limite da teoria do desejo, tensão que é necessária a partir do momento em que o problema da angústia se coloca. Embora estejamos delimitando a presente discussão ao contexto do Seminário 10, é necessário considerarmos algumas questões incitadas pelo Seminário 7, A ética da psicanálise (LACAN, 19591960). Lembremos que Lacan afirma, nesse Seminário, que é em torno de das Ding "que se orienta todo o encadeamento do sujeito" (LACAN, 1959, p.69). Nesse sentido, é preciso compreender a articulação do desejo nesse momento da obra 
desse autor para localizarmos a extração da noção de objeto a alguns anos depois, noção que passa a designar esse ponto último de determinação do sujeito.

O psicanalista Marcus André Vieira aborda esse assunto em sua obra $A$ Ética da paixão — uma teoria psicanalítica do afeto (2001). Na trajetória lacaniana do desejo, ele focaliza o Seminário 7, em que o desejo é pensado a partir de das Ding. Vieira ressalta, desse contexto, o estabelecimento de novas balizas para o problema do desejo, já que este aponta para o horizonte ético da insondável decisão do ser, desnudado de suas vestes semânticas (2001). Assim, “o grafo do desejo será momentaneamente deixado de lado, pois ele apenas aponta o que Lacan agora precisa abordar mais diretamente. Trata-se de tomar o desejo em sua face mortífera, de articular o que, do gozo, se introduz no campo humano" (Idem, p.121). O questionamento ético em torno do desejo marca o sétimo seminário de Lacan e traz importantes consequências para a práxis psicanalítica. É possível depreender da reflexão de Vieira que, a partir desse enfoque do desejo ocasionado pelo questionamento ético, o movimento teórico lacaniano que conduzirá ao objeto a ganha bases mais sólidas. Vieira sintetiza esse movimento, afirmando que:

\begin{abstract}
“Lacan, após estabelecer o horizonte de sua investigação, seu sujeito e a matériaprima do trabalho analítico, apoia-se nas formulações do inconsciente para delinear um campo para o desejo de onde extrai um elemento, Coisa fundamental, que inaugura a possibilidade de uma nova ética. Aplica-se então à transferência e chega, assim, à estrutura topológica do sujeito - explicitada especialmente no seminário sobre a identificação — , o que permite retornar com novas ferramentas à questão da angústia e, enfim, aos quatro conceitos que considera fundamentais para a psicanálise. Este momento marca um corte e o fim de um percurso, com a introdução do objeto a. Deste modo, o objeto a, criado a partir da angústia, a ressignifica a partir do horizonte ético que ele mesmo descortina." (VIEIRA, 2001, p.121-122)
\end{abstract}

Essa breve recapitulação alinhava os passos do caminho de Lacan, de forma a deixar explícito o caráter operatório do objeto a. Tal noção surge como um operador teórico fundamental para permitir os novos rumos da teoria do desejo. Mais do que redimensionar o problema do desejo na psicanálise, o objeto a garante à angústia, que foi o ensejo de sua formulação, uma nova significação ética. Como assinala Vieira, esse recorte progressivo do percurso lacaniano permite "destacar uma certa sucessão das maneiras pelas quais Lacan procura, neste período, contornar o real, que encontra uma formulação mais decisiva com a nomeação do objeto a" (VIEIRA, 2001, p.122). 
O mergulho que Lacan empreende no campo da angústia traz à tona o limite do desejo, as bordas do gozo. Este último, que será, a partir de então, bastante problematizado por Lacan em formulações lógicas cada vez mais complexas, recebe, nesse contexto, um tratamento mais simplificado. Nesse momento de formulação do objeto a, o gozo é mais abordado como oposto à ordem significante, como o que não se deixa apreender pela cadeia da linguagem. A concepção de gozo apresentada nesse Seminário é essencial, pois ela reinsere na discussão psicanalítica toda a dimensão do corpo. Levando-se em conta um organismo que goza, que é constituído por órgãos reais e erógenos, é preciso um elo para garantir tanto o avanço na compreensão do desejo como também o manejo da clínica psicanalítica, que não pode mais ser a mesma a partir desses novos parâmetros. O objeto a passa ao centro da discussão clínica, e isso se deve a sua função de causa e a seu caráter de borda. Como atesta Vieira, “a partir deste objeto, garantia da certeza, ordenam-se desejo e gozo” (VIEIRA, 2001, p.138). Ao que podemos acrescentar que se reordenam as balizas da prática clínica de orientação lacaniana, que passa a lidar, então, com um desejo que tem como causa o objeto a.

Bernard Baas também nos oferece uma leitura que privilegia a reordenação da teoria lacaniana do desejo a partir da angústia e do objeto a. Em seu artigo “A angústia e a verdade" (2001), ele destaca que a inquietação de determinar o objeto causa da angústia prevalece em toda a evolução da teoria de Freud sobre tal afeto (Idem). Para chegar à perspectiva lacaniana sobre a angústia, Baas passa por uma breve "analítica do desejo", síntese da concepção construída por Lacan no Seminário sobre a ética. O autor relembra que o sujeito só se relaciona aos objetos do desejo pela rede de significantes, mas que o desejo procede, em sua origem, da falta (Idem). A falta é tratada nesse seminário a partir da noção freudiana de das Ding, a Coisa, que não é um objeto que faz parte do mundo se considerarmos que o mundo é o que se constitui para o sujeito através da rede de significantes.

Relembrando que a Coisa não é um objeto empírico do desejo, mas sim a falta de onde provém o desejo, Baas explica essa procedência enigmática evocando a noção de objeto a. Ele passa, assim, do contexto teórico do Seminário 7 ao centro da questão sobre a angústia. Para ele, “o desejo procede da falta que é a Coisa, mas não pode dar-se esta falta, a Coisa, como objeto (que seria o gozo), porque a Coisa, enquanto é — como diz Lacan — fora-significante e fora-significado, não poderia ser visada através da rede de significantes" (BAAS, 2001, p.73). Dessa forma, coloca-se o que esse autor considera como o problema mais difícil: como o desejo, que procede do nada da Coisa, pode se relacionar ao objeto empírico do desejo? É para solucionar esse problema que Lacan lança mão, três anos depois do Seminário sobre a ética, da ideia de objeto a. Segun- 
do Baas, o objeto a é o elemento intermediário que torna possível a síntese da pura falta com o objeto empírico, "síntese que se chama — simplesmente - o desejo" (Idem, p.73-74).

Com isso, podemos vislumbrar a condição de causa e de borda que o objeto a ocupa na estrutura do desejo, condição que provém da característica específica desse objeto: ser resto da operação significante. É por ser um resto irredutível ao significante que o objeto a pode se ligar a um pedaço separável do corpo, tornando-se, assim, articulador desses que são objetos empíricos, carnais, àquele que é o objeto absolutamente inapreensível, a Coisa. Nessa função de fazer a borda entre o real e o simbólico engendra o desejo. Se o desejo é, para Baas, uma síntese, é porque ele se constitui como desejo do objeto empírico, por um lado, ancorado na cadeia significante, e, ao mesmo tempo, procede da Coisa, que é bordejada pelo objeto a.

A análise que Baas efetua do papel do objeto a na constituição do desejo o conduz a uma abordagem contundente do problema da angústia: o sujeito alienado pelo significante é eclipsado ao se deparar com o nada de significante (Idem). Eis aí a invasão da angústia, que demarca o instante em que o desejo retrocede aquém da cadeia da linguagem e encontra o objeto que o causa. O horror que caracteriza esse encontro com o nada é da mesma ordem daquele que se instala no Unheimlich, como Freud (1919) tão bem o descreveu e que Lacan valoriza em algumas aulas do Seminário 10. Referindo-se a uma afirmação de Lacan, Baas sustenta que a angústia é o afeto por onde passa a "função pura do desejo". Trata-se do movimento em que o desejo se relaciona à verdade da falta que é sua procedência, e essa relação se dá, nesse caso excepcional demarcado pela incidência da angústia, de maneira imediata, ou seja, sem a mediação dos significantes. Para o autor, é por isso que a angústia é o que não engana, proposição lacaniana que ele interpreta assim: a angústia é “o indicador infalível da verdade da falta, signo verdadeiro da verdade” (BAAS, 2001, p.75).

Desse modo, Baas propõe que a angústia e o objeto a tocam em um ponto de verdade. Podemos compreender o lugar lógico indicado pela angústia como aquele no qual a formulação de um operador extralinguístico - ao mesmo tempo causa do desejo e borda do real — possibilita vislumbrar a verdade do desejo como aquilo que concerne ao âmago da mensagem freudiana. Trata-se daquilo que diz respeito à razão de ser da psicanálise, como práxis que responde a um mal-estar proveniente de um corte originário, cindido no ato inaugural de entrada do sujeito na linguagem. Tendo tudo isso em vista, visamos focalizar, no próximo tópico, a reflexão que Lacan empreende acerca da verdade e do engodo do desejo. 


\section{UM ENGODO ESTRUTURANTE}

No Seminário 10, a questão do engodo do desejo torna-se fundamental na medida em que o problema da verdade se coloca. A dicotomia verdade-engano remete ao que diz respeito à singularidade mais radical e irredutível do sujeito - singularidade que decorre da constituição desse sujeito como um ser movido por um desejo que é causado pelo objeto a. A angústia é definida de maneira enfática como o afeto que não engana precisamente por ser o afeto que sinaliza essa procedência do desejo.

Em vista disso, fica evidente em que medida é inadiável, para Lacan, tratar desse ponto de verdade, bem como de suas implicações para a clínica psicanalítica. Mas, e quanto ao engodo do desejo? A que concerne o caráter enganoso do desejo? Para responder a essa questão, é preciso seguir algumas pistas deixadas pelo autor. De início, constata-se que é para deslindar a trama em torno desse problema que Lacan se propõe a situar o ponto de junção entre o complexo de castração - em que o objeto a funciona como o falo que falta - e o nível visual do desejo - nível em que se pode compreender melhor o que significa o engodo do desejo (LACAN, 1963).

Destaquemos um debate em torno das conclusões de Freud em Análise terminável e interminável (1937), por meio do qual Lacan apresenta sua concepção dos limites de uma análise e do complexo de castração. Ao se desvencilhar do paradigma freudiano da angústia de castração como última barreira ao término de uma análise, Lacan se aproxima da questão aqui examinada. Essa obra freudiana é aquela em que o autor expressa com especial clareza e veemência suas reservas quanto à eficácia da psicanálise em uma perspectiva terapêutica. Ele declara não acreditar em uma verdadeira "cura” pela psicanálise, na medida em que o conflito psíquico, sob a forma de sintomas, angústias ou inibições, pode retornar mesmo após anos de tratamento.

A principal razão apontada por Freud para essa “ineficácia” está na própria gênese do conflito psíquico, que é erigido sobre um conflito pulsional em que a pulsão de morte é preponderante. Para ele, a pulsão de morte é intensa demais para que seus efeitos sejam suprimidos pela análise de forma definitiva. Nas palavras do autor, "temos de nos curvar à superioridade das forças contra as quais vemos nossos esforços redundar em nada” (FREUD, 1937, p.260). À intensidade dessa força pulsional alia-se um importante elemento: a pulsão de morte é contínua, perene, incessante.

Além dessa força descomunal da pulsão de morte, Freud salienta a angústia de castração como um fator decisivo no impedimento do êxito de uma análise. Sobre a "atitude para com o complexo de castração" (FREUD, 1937, p.268) tanto em homens como em mulheres, admite que "em nenhum ponto de nosso trabalho analítico se sofre mais da sensação opressiva de que todos os nossos 
repetidos esforços foram em vão, e da suspeita de que estivemos 'pregando ao vento"” (Idem, p.269).

Lembrando que tudo o que se sabe de absolutamente novo e original a respeito da estrutura do sujeito e da dialética do desejo se deve à experiência, inaugurada por Freud, do tratamento psicanalítico do neurótico, Lacan (1962) situa o último termo a que Freud chega em sua elaboração sobre essa experiência na angústia de castração. Entretanto, essa intransponibilidade da castração é rebatida com sua argumentação:

“Aquilo diante de que o neurótico recua não é a castração, é fazer de sua castração o que falta ao Outro. É fazer de sua castração algo positivo, ou seja, a garantia da função do Outro, desse Outro que se furta na remissão infinita das significações, desse Outro em que o sujeito não se vê mais do que como um destino, porém um destino que não tem fim, um destino que se perde no oceano das histórias. (...) O que pode assegurar uma relação do sujeito com esse universo de significações senão que, em algum lugar, existe gozo? Isso ele só pode assegurar por meio de um significante, e esse significante falta, forçosamente. Nesse lugar de falta, o sujeito é chamado a dar o troco através de um signo, o de sua própria castração." (LACAN, 1962, p.56)

Se um sujeito em análise utiliza sua própria castração como um signo para tamponar a falta, não se pode mais avançar. É esta a barreira intransponível na concepção lacaniana. Na experiência analítica, o sujeito precisa se haver com a falta de outra maneira, aquela que será a sua maneira e que é, em última instância, a construção singular que ele fará para se posicionar na modalidade de gozo que lhe é própria. Se não é o falo ausente na castração o signo capaz de assegurar esse posicionamento, a noção de objeto a é uma solução possível para esse impasse. A partir da introdução dessa noção, constata-se que o caminho possível para se sustentar a relação do sujeito com o desejo passa por outro lugar.

Lacan indica que "dizer que o desejo é ilusão é dizer que ele não tem sustentação, não tem escoadouro, sequer tem ambição em relação a nada” (1963, p.245). Eis aí o oceano de significações sem escoadouro. O autor retoma essa problemática introduzindo às claras o objeto a como causa do desejo:

"O desejo é ilusório, por quê? Porque sempre se dirige a um outro lugar, a um resto, um resto constituído pela relação do sujeito com o Outro que vem substituí-lo. Mas isso deixa em aberto a questão de saber onde pode encontrar-se a certeza. Nenhum falo permanente, nenhum falo onipotente é próprio por natureza para fechar, seja pelo que for de apaziguador, a dialética da relação do sujeito com o Outro e com o real. Se com isso tocamos na função estruturante do engodo, será que isso quer 
dizer que devemos ficar por aí, confessar nossa impotência, nosso limite e o ponto em que se rompe a distinção entre a análise finita e a análise indefinida? Creio que não. (...) É aí que intervém o que se encerra na essência mais secreta do que tenho anunciado, há muito tempo, sob a forma do estádio do espelho, e que nos obriga a tentar ordenar numa mesma relação o desejo, o objeto e o ponto de angústia - a saber, esse novo objeto a (...): o olho." (LACAN, 1963, p.262)

O falo onipotente, portanto, não obtura a falta. A castração não é a resposta definitiva para o dilema do neurótico em sua saga de sujeito desejante. Lacan nos lembra que é no campo visual que se faz a primeira abordagem da presença fálica, e isso se faz de um modo traumático, a cena primária. Sendo assim, toda essa elaboração sobre a angústia de castração se mostra atrelada à dimensão imaginária. O campo visual é aquele em que o problema do engodo do desejo se coloca de forma mais radical.

Abordamos esse tema a partir da definição de que o desejo ligado à imagem é função de um corte que sobrevém no campo do olho (LACAN, 1963). Como em qualquer outro nível, é um corte que produz o objeto a visual. Por meio desse corte, o olho é um espelho, espelho que é o "campo do Outro em que deve aparecer pela primeira vez, se não o a, pelo menos seu lugar — em suma, a mola radical que faz passar do nível da castração para a miragem do objeto do desejo" (Idem, p.251).

No campo da imagem, o corte diz respeito à função especular. O olho é um espelho que organiza o mundo como espaço. Ele delimita o indivíduo de todo o espaço exterior e, ao mesmo tempo, é o principal elo daquele que vê com o espaço que é visto. A experiência especular garante um primeiro delineamento do campo do objeto. Separa-se, então, o eu dos outros e se instaura uma dupla via identificatória: a identificação com a própria imagem especular e com a imagem dos outros. Essa função da imagem especular antecede e possibilita a constituição do sujeito.

Lacan nos apresenta o olho como o órgão que garante a capacidade mimética de um indivíduo, base da identificação. A identificação depende sempre de certo componente de fascínio que faz parte da função do olhar. A fascinação, por sua vez, está vinculada à principal característica dessa nova forma do a. Trata-se do que o autor chama de "ponto zero" do olhar, ponto de contemplação em que ocorre uma suspensão frágil do dilaceramento do desejo, suspensão que ele compara a "uma cortina sempre pronta a se reabrir para desmascarar o mistério que oculta" (Idem, p.264).

Essa posição contemplativa do olhar, esse ponto zero em que o objeto a se aloja, tenta anular o mistério da castração. Se o próprio olhar se perde em um ponto do espaço em que o objeto se localiza, tal objeto ganha contornos e nuances que 
o anulam como a falta que causa o desejo. O objeto se torna fascinante, digno de contemplação, o que mascara sua dimensão de real. Daí o relativo apaziguamento da angústia que caracteriza o desejo nesse nível. Conforme Lacan, nesse ponto de fascínio, o desejo visual às vezes mascara a angústia daquilo que, em essência, falta no desejo. "A relação recíproca entre o desejo e a angústia apresenta-se, nesse nível específico, sob uma forma radicalmente mascarada, que está ligada às funções mais enganosas da estrutura do desejo” (LACAN, 1963, p.278). Eis aí uma primeira resposta ao problema do engodo: nesse nível do desejo, a angústia está mascarada, ainda que se trate de um mascaramento provisório, tênue e efêmero - afinal, a cortina está sempre pronta para se abrir.

Lacan esclarece que a definição da angústia como o afeto que se instala quando o sujeito se percebe diante do desejo do Outro é válida apenas para o nível escópico do desejo (LACAN, 1963, p.353). Nesse nível do mascaramento, a angústia se deve ao fato de um sujeito não saber que objeto a ele é para o desejo do Outro. Esse desconhecimento decorre de uma alienação fundamental, marca da fantasia, que a estrutura do desejo só desenvolve de maneira plena no nível escópico. E essa alienação do objeto a, que nesse nível é confundido com um “ponto zero", possibilita ao sujeito certa garantia quanto à angústia (Idem). Para avançarmos nesse assunto, é necessário compreender a passagem que se faz entre a castração e o nível da imagem. Isso permite examinar a forma emblemática que essa alienação assume: a fantasia.

Em sua refutação da angústia de castração como o impasse supremo do neurótico, Lacan atribui o caráter de "castração imaginária” à fratura que se produz por meio de uma aproximação da imagem libidinal de um semelhante (Idem, p.56). Aí estão os “acidentes da cena”, incidentes, reais ou não, que constituem a cena traumática — tão fundamental na formação da angústia e presente de forma marcante nos momentos primitivos da subjetivação. Essas fraturas fazem parte da primeira constituição do eu que se passa no nível imaginário. Com o advento da função da imagem especular e a concomitante formação do eu, o horror das imagens fragmentadas do corpo cede lugar à visão de um corpo uno, delimitado. A cena traumática, decorrente das fraturas inevitáveis causadas pela visão de recortes do real — cujo exemplo mais emblemático é a visão do ato sexual — , por um bebê sem uma estrutura subjetiva mínima capaz de dar sentido ao que é visto permanece como o mosaico formado pelos cacos do espelho que serão emendados pela cena da fantasia.

É também a cena da fantasia que permite a visualização do que não é captado pela imagem especular. A aparição do objeto a nessa imagem só pode ser sustentada por meio de um artifício, de um recurso ilusório. A outra forma de aparição do "a" no campo visual não pode contar com a atenuação decorrente do artifício que é a fantasia. Trata-se do fenômeno do estranho, que está 
mais ligado à dimensão da verdade e que comentaremos no próximo tópico. A fantasia está mais próxima da dimensão de engano do desejo. Ela é sempre erigida sobre um modelo visual, e, por isso, é o suporte mais satisfatório da função do desejo (LACAN, 1963 p.276), já que consegue sustentar o desejo pela via de uma ficção, esta sim acessível para o sujeito por meio do dispositivo analítico.

Em outras palavras, a fantasia é a construção possível que o desejo erige em torno de um sentido para o que não tem sentido. Para Lacan, o desejo é desejo de desejo (LACAN, 1962, p.34). O que fomenta o desejo é algo que está fora do campo do sentido. Na cena fantasmática, forja-se, de maneira artificial, um sentido para o desejo, mesmo que seja um sentido absurdo, bizarro, grotesco. De qualquer forma, é algo que se vê e se nomeia. É o recobrimento ilusório do que não pode ser visto.

Podemos considerar, portanto, que o nível escópico do desejo é aquele em que a dicotomia verdade-engano se faz presente de maneira mais nítida porque, nesse nível, o objeto a, que é impossível de se capturar pela imagem, ganha uma localização no campo visual. É a fascinação tão evidente, por exemplo, no papel que a atração visual exerce no âmbito do desejo sexual. Atração que se alastra, inclusive, por todo o universo absolutamente fascinante para o olhar que é o campo do objeto de consumo. É ilusório o desejo guiado pelos atributos visíveis de um objeto. Mas essa ilusão é estruturante, como ressalta Lacan (1963). Por quê? Porque é preciso que haja uma estrutura ficcional para que o sujeito, barrado pelo significante, sustente sua relação com um movimento desejante que é, afinal, decorrente da falta. Não se pode lidar com o desejo sem sentido, o desejo de desejo, enfim, o desejo do Outro sem que se encubra ao menos um pouco o vazio que há no fundo da imagem. O desejo, em si, é inacessível ao sujeito. É por isso que a fantasia viabiliza, ainda que de forma indireta, a relação do sujeito com seu desejo. É o artifício que permite encobrir a falta atroz, inexorável, que é a verdade do desejo.

Ao analisar a questão do engano do desejo no Seminário 10, Jacques-Alain Miller (2005) enfatiza que o objeto a está do lado do sujeito, e não do lado do Outro. "O lugar autêntico do a está do lado do sujeito, invisível para ele, e só está no Outro por engodos e falácias” (Miller, 2005, p.53). Assim, o desejo é um engano porque tem sempre uma falsa finalidade, um engano em relação ao objeto de que se trata (Idem, p.49). Sua meta, sua finalidade, é sempre um objeto-visado que substitui o a. Esse autor esclarece que Lacan passa a considerar o pequeno a da fantasia do neurótico como um a postiço, uma falsificação, um deslocamento indevido no Outro. Ao encenar o a, a fantasia transforma esse objeto em um objeto-visado, nos termos de Miller. É por isso que se trata de um engano. E isso é essencial, na medida em que há todo um movimento 
nesse seminário que sinaliza a exterioridade do objeto a em relação ao campo do Outro. Miller elucida:

“A fantasia neurótica é colocada como inautêntica e o objeto a da fantasia do neurótico apenas como um substituto. Permanece, nesse Seminário, a noção de que o verdadeiro de verdade, o verdadeiro objeto a, não pode ser visto. (...) Lacan constrói os objetos-causa como não especularizáveis, eles não podem ser capturados no espaço do espelho, no campo escópico, eles escapam ao campo visual. Por isso, o que Lacan chama de campo do Outro no Seminário $A$ angústia é o lugar do significante, mas também o lugar das aparições, é ali que eles aparecem.” (MILLER, 2005, p.52-53)

Miller (2005) enfatiza certa desqualificação que Lacan executa do imaginário. Se o Outro, tal como o imaginário, é o lugar do engano, do que não é autêntico em relação ao a, a verdade se encontra em outro lugar. E esse lugar está aquém do desejo e aquém do significante. Ele observa que essa reflexão de Lacan vai culminar, mais tarde, na noção de semblante, como tudo aquilo que concerne ao campo do significante. Para ele, o caráter duvidoso do significante contrasta com a certeza da angústia, que provém de sua conexão com o real do gozo (Idem, p.54).

A angústia é justamente o que sinaliza o ponto da verdade do desejo, ponto que está aquém do desejo, daí sua definição como aquilo que não engana. É sobre esse atributo da angústia — tão bem designado pela expressão "a agudeza da angústia”, mencionada por Lacan logo no início do seminário (1962, p.24) — que voltaremos nossa atenção no tópico seguinte.

\section{A ANGÚSTIA E A VERDADE DO DESEJO}

Os desdobramentos expostos no tópico anterior evidenciam que a certeza da angústia está relacionada à sua conexão com o gozo. Por conseguinte, a verdade do desejo está aquém do desejo, na falta que é sua origem. E a metonímia que é a constituição significante do desejo corresponde à tentativa incessante de preenchimento dessa falta original, tentativa sempre vã e ilusória, pois os objetos visados pelo desejo, inscritos na lógica significante, não conseguem recobrir por inteiro o real, que apenas o objeto a bordeja. O Seminário 10 revela a inerência radical do gozo ao registro do real. Segundo Miller, a abordagem da angústia possibilita que o gozo se libere da amarração significante de sua prisão fálica (MILLER, 2005, p.28). E isso ocorre em virtude da sinalização efetuada pela angústia dos pontos de incidência do gozo no corpo sob a forma dos objetos a. 
É ao gozo que Lacan se refere com sua definição “a angústia é o que não engana”. Conforme Miller, o que não engana é o que não se deixa significantizar, é o resto. Esse resto real é o gozo irredutível ao princípio de prazer e a angústia é o afeto de desprazer que conota o não-significantizável (MILLER, 2005). Essa conexão entre a angústia e o gozo é esclarecida no trecho que se segue:

“Tentemos agora apreender no concreto essa relação singular do gozo com a angústia. Para isso, é preciso ir a Freud, que nos diz que a primeira e mais originária das condições determinantes da angústia é a exigência pulsional, constantemente crescente, diante da qual o eu está em estado de aflição. (...) A tradução dessa frase em termos lacanianos já leva vocês a percorrer a relação do gozo com a angústia. Trata-se, para Freud, de uma perturbação econômica, um excesso (...) de libido inutilizada que é o núcleo do perigo ao qual a angústia responde. Nos termos de Freud, o que foi articulado por Lacan é a relação do gozo com a angústia e, por trás da angústia, a pulsão enquanto ela quer se satisfazer, enquanto vontade de gozo, insistindo sem trégua. Quando essa insistência pulsional entra então em contradição com o princípio do prazer, há esse desprazer que se chama angústia." (MILLER, 2005, p.54)

Esse esclarecimento é especialmente importante porque alinhava a chegada de toda a trajetória freudiana ao ponto em que Lacan localiza a certeza da angústia. Para Freud, a angústia sinaliza o perigo de um excesso libidinal, o que fica claro em sua última abordagem do tema na Nova conferência "Ansiedade e vida instintual" (1933). Lacan compreende esse excesso como aquilo que extravasa a linguagem, como o que, do corpo, ultrapassa toda a tentativa de apreensão significante.

O objeto a é o termo inferido a partir da angústia para designar a borda derradeira entre esse excedente do corpo e a linguagem. A introdução do a efetua, na teoria lacaniana, uma inovação sem precedentes em relação à abordagem do corpo. Miller demonstra essa inovação, ressaltando o movimento que se passa entre uma concepção de corpo como passível de ser significantizado - o corpo tal como é concebido pela proposta do estádio do espelho, o corpo visível, da imagem corporal unificada - para outra concepção, a de um corpo que ultrapassa o significante, um corpo ao qual são restituídas todas as suas particularidades anatômicas (MILLER, 2005, p.19). O objeto a concerne a esse corpo visceral, anatômico, o que se explicita em sua capacidade de se localizar em partes específicas desse corpo, os objetos cedíveis. Essa capacidade está ligada justamente à sua função última que é bordejar o gozo, o que ocorre nas zonas erógenas.

O que Miller chama de "crueza” do Seminário 10 (MILLER, 2005), essa abordagem nua e crua das particularidades anatômicas do corpo, é consequência da função sinalizadora da angústia. Ao sinalizar a verdade do desejo, a angústia 
desvela o corpo em toda a sua condição de organismo, no real de seus órgãos. E a certeza da angústia está atrelada de maneira intensa a essa verdade anatômica do corpo, o que fica evidente no momento de sua incidência, quando todo o corpo, incluindo seu ritmo cardíaco e respiratório, é acometido por esse afeto.

Outra vertente da certeza que a angústia demarca se situa em sua oposição ao caráter ilusório da fantasia. Lacan compara a estrutura da angústia à estrutura da fantasia desde o Seminário 8 (1961) — ambas se apresentam como algo enquadrado. Em referência à verdade-engano, o confronto dessas duas cenas pode ser definido nos seguintes termos: enquanto a fantasia é a cena que assegura ao sujeito uma relação mediada com seu desejo por uma ficção, e, por isso, caracteriza-se por sua função de mostrar o objeto de forma velada, a angústia, por outro lado, é a cena na qual o objeto se apresenta sem véu, sem qualquer encobrimento.

Trata-se do ponto de encontro do desejo com a dimensão do gozo. É a aparição do objeto a em sua realidade nua e crua, sem fantasias, sem qualquer montagem artificial. Na angústia, acabaram-se as ilusões tão importantes para o sujeito. Daí seu desvanecimento, sua vacilação enquanto sujeito. É o abalo daquilo que é estruturado pela vertente enganosa do desejo, ou seja, pelo significante. Tal vertente é abruptamente interrompida para dar lugar ao gozo. O Unheimlich é o exemplo máximo dessa cena de angústia.

A diferenciação entre essas duas estruturas fundamentais acarreta ainda outras implicações. Tomemos, de um lado, a definição da angústia, proposta no Seminário 8, como o que marca o nível mais radical de sustentação do desejo (LACAN, 1961). Do outro lado, está a fantasia como sustentação mais satisfatória do desejo, com seu enredo ficcional que substitui o "a” por um objeto postiço. A cena que deflagra a angústia, por sua vez, ao invés de viabilizar um enredo para o inomeável do desejo, aponta esse inomeável. Essa cena acarreta um acometimento afetivo que faz o sujeito vacilar. Isso acontece porque a angústia é a única a almejar a verdade da falta a que se liga à satisfação do desejo (LACAN, 1963, p.253) — daí ser o indicador do nível mais radical de sustentação do desejo.

Toda a problemática exposta até aqui nos reenvia à discussão ética a respeito da angústia, como situam os autores já apresentados neste estudo, Marcus André Vieira e Bernard Baas. No entendimento de Vieira, a formulação do objeto a a partir da teoria da angústia resulta de um processo de questionamento ético norteado, a partir do Seminário 7, pela face de gozo do desejo. E a introdução desse operador teórico fundamental, o “a”, conduz a uma ressignificação ética da angústia, como já foi acentuado. Acreditamos que essa ressignificação ética está profundamente ligada à questão da verdade que a angústia encerra. Vieira define a angústia como o afeto paradigmático que se introduz no ponto em que um sujeito aparece entre desejo e gozo. "Mais especificamente, ela é 
aquilo que retém o sujeito na borda de seu desejo, constituindo um anteparo contra o gozo." (VIEIRA, 2001, p.97). O ponto de verdade do desejo se localiza, então, em seu limiar ante o gozo. E o gozo está no cerne do questionamento lacaniano sobre a ética. Acerca da ética da psicanálise, Vieira esclarece:

“A ética se compreende como maneira de falar de uma articulação não arbitrária mas necessária, entre saber e gozo, dizendo respeito à região (...) onde estes dois domínios enovelados fazem Um, exatamente em seu ponto de disjunção. Trata-se do ponto onde se revela a singularidade de cada caso, subjetivada na angústia." (VIEIRA, 2001, p.142).

A elaboração de Bernard Baas é circunscrita em torno do problema da verdade. Também partindo do Seminário 7, esse autor salienta que, para Lacan, a verdade da Coisa não pode se mostrar como tal na ordem significante (BAAS, 2001). Essa verdade só é deduzida por meio de um índice infalível que a denuncia. Para ele, “a angústia é assim o signo sensível da verdade da coisa, isto é, disto que excede o desejo e de que, no entanto, o desejo procede" (Idem, p.75).

De acordo com Baas, a perspectiva lacaniana propõe a angústia não como um afeto que acompanha tal significante ou tal combinação de significantes, mas sim como o afeto que remete para além da rede de significantes. A angústia aponta a pura falta como condição de possibilidade de qualquer desejo, posto que o desejo se constitui no significante (Idem). Assim, esclarece-se a tese defendida por esse autor: "a angústia é a afecção que marca a verdade” (Idem, p.76). Ele sublinha que o termo extimidade, forjado por Lacan para caracterizar o objeto a, designa com precisão esse ponto de verdade que é marcado pelo surgimento da angústia. Como evidencia a experiência do Unheimlich, o que angustia, o que inquieta e causa horror concerne ao mais íntimo, ao mais “de casa”, à verdade do sujeito, enfim. A extimidade do objeto a diz respeito a uma espécie de encontro horripilante com a pura falta da Coisa, quando o sujeito do desejo toca naquilo que há de mais profundo, de mais originário e de mais íntimo, naquilo de que depende seu desejo, e que, ao mesmo tempo, é totalmente estrangeiro para o sujeito e exterior à ordem significante que é a morada habitual do desejo (BAAS, 1992).

Conforme Lacan, a angústia designa o objeto mais profundo e derradeiro, a Coisa (LACAN, 1963). E o objeto a, em sua função de borda, encarna o impasse do acesso do desejo a esse objeto derradeiro. Se o desejo procede da Coisa, como borda, como a barreira de acesso à Coisa, o objeto a é o que causa o desejo, possibilitando a referência que os objetos empíricos têm à Coisa. O sentido de causa tem, aqui, todo o seu valor e é através dele que prossegue nossa investigação.

A questão da verdade que é designada pela angústia alude, então, à essência do objeto a: sua função de causa do desejo. É pela via da causa que podemos 
compreender o sentido mais radical da conexão angústia-objeto a. Tal objeto não é a finalidade nem a meta do desejo, mas sua causa, na medida em que o próprio desejo é algo não efetivo, um efeito constituído na função da falta (LACAN, 1963). É como resto irredutível ao significante que o “a” atua como a hiância que causa o desejo, tornando-se o referencial latente para a metonímia do desejo na cadeia significante.

O objeto a é postulado como o que antecede o sujeito. É o real do corpo anterior a qualquer delineação imaginária, anterior à ordenação simbólica. Com o advento do sujeito no lugar do Outro, esse objeto se torna vestígio, resto de algo que não pertence a um mundo constituído na lógica significante, como o agalma dos antigos gregos, objeto que era deixado na tumba junto a um cadáver e que correspondia ao que melhor o designara, em vida, com o intuito de acompanhálo no "mundo dos mortos" (QUIGNARD, 2005). O objeto a também é o elo entre dois mundos: o real e o simbólico. A angústia sinaliza, no simbólico, o real sempre que esse objeto se apresenta. Ao sinalizar o real, a angústia demarca a verdade que há por trás do engodo do desejo.

Para Miller, Lacan promove, por meio dessa movimentação do Seminário 10, um rebaixamento do desejo. Esse termo, tão importante nos Seminários anteriores, passa a designar algo que concerne a um engano, cuja finalidade é sempre uma falsa finalidade (MILLER, 2005). O autor observa que "tudo isso será em seguida ajustado, temperado, deslocado por Lacan, mas ali estamos no momento em que emerge toda uma outra dimensão da experiência que até então não havia sido aberta" (Idem, p.55). Assim, é possível atribuir ao Seminário 10 uma mudança de coordenadas (Idem) naquilo que norteia o ensino de Lacan, que, doravante, passa a lidar com um desejo-engodo que tem como causa o objeto a.

Portanto, a discussão em torno da questão da verdade demarcada pela incidência da angústia exerce um papel essencial nessa mudança de coordenadas, visto que há, então, toda uma abertura para a abordagem do campo do gozo. Até esse momento, a concepção de gozo estava por demais emaranhada na trama significante, não sendo possível depreender daí todas as implicações da dimensão real do gozo para o problema do desejo. A partir do momento que Lacan executa uma distinção entre a face de gozo do desejo, referenciada pela certeza da angústia - e que, no Seminário 10, relaciona à verdade do desejo - e a vertente de engano - atrelada à determinação significante do desejo e explicitada, sobretudo, pelo nível visual do desejo - ocorre uma reviravolta na perspectiva lacaniana, que tem como principal resultado certo “rebaixamento" do desejo. Como assinala Miller (2005), esse termo, o desejo, tão importante nos seminários anteriores, passa a designar algo que concerne a um engodo. E isso é fundamental para essa mudança de coordenadas que se concretiza na prática clínica de orientação lacaniana, que passa a buscar esse 
átimo da verdade de um sujeito em outro lugar: não mais na interpretação do desejo, mas sim nos acontecimentos que aludem ao real, tais como a invasão da angústia.

Recebido em 12/2/2009. Aprovado em 27/6/2009.

\section{REFERÊNCIAS}

BAAS, B. (2001) "A angústia e a verdade”, in O desejo puro. Rio de Janeiro: Revinter.

FREUD, S. (1996) Edição standard brasileira das obras psicológicas completas de Sigmund Freud. Rio de Janeiro: Imago.

(1919) “O estranho”, v.XVII, p.235-269.

(1926) "Inibição, sintomas e ansiedade", v.XX, p.81-167.

(1933) "Nova conferência introdutória sobre psicanálise: Ansiedade e vida instintual”, v.XXII, p.85-112.

(1937) “Análise terminável e interminável”, v.XXIII, p.225-270.

LACAN, J. (1959-1960/1997) O Seminário livro 7, A ética da psicanálise. Rio de Janeiro: Jorge Zahar Editor. . (1960-1961/1992) O Seminário livro 8, A transferência. Rio de Janeiro: Jorge Zahar Editor.

. (1962-1963/2005) O Seminário livro 10, A angústia. Rio de Janeiro: Jorge Zahar Editor.

. (1968-1969/2008) O Seminário livro 16, De um Outro ao outro. Rio de Janeiro: Jorge Zahar Editor.

. (1969-1970/1992) O Seminário livro 17, O avesso da psicanálise. Rio de Janeiro: Jorge Zahar Editor.

MILLER, J-A. (2005) Introdução à leitura do Seminário da angústia de Jacques Lacan. Opção Lacaniana, n.43. São Paulo: Edições Eolia, p. 7-91.

QUIGNARD, P. (2005) "L'invention de l'objet petit a", in Sordidissimes. Paris: Gallimard, p.48-54.

VIEIRA, M. A. (2001) A ética da paixão: uma teoria psicanalítica do afeto. Rio de Janeiro: Jorge Zahar Editor.

Daniela Teixeira Dutra Viola daniela.dutraviola@gmail.com

Ângela Maria Resende Vorcaro angelavorcaro@uol.com.br 